\title{
A cross sectional study to assess the need of urodynamic studies in lower urinary tract patients attending an urogynaecology clinic
}

\author{
Deepa Joshi*1, K. Lalitha ${ }^{2}$, Piyush Joshi ${ }^{3}$, Satish Saroshe ${ }^{4}$
}

\begin{abstract}
${ }^{1}$ Department of Obstetrics and Gynecology, Arihant Hospital and Research Centre, Indore, Madhya Pradesh, India
${ }^{2}$ Department of Urogynecology, Century Super speciality Hospital, Hyderabad, Telangana, India

${ }^{3}$ Department of Internal Medicine, Arihant Hospital and Research Centre, Indore, Madhya Pradesh, India

${ }^{4}$ Department of Community Medicine, M.G.M Medical College Indore, Madhya Pradesh, India
\end{abstract}

Received: 04 October 2016

Accepted: 08 October 2016

\author{
*Correspondence: \\ Dr. Deepa Joshi, \\ E-mail: dr_deepajoshi@yahoo.com
}

Copyright: () the author(s), publisher and licensee Medip Academy. This is an open-access article distributed under the terms of the Creative Commons Attribution Non-Commercial License, which permits unrestricted non-commercial use, distribution, and reproduction in any medium, provided the original work is properly cited.

\begin{abstract}
Background: Urodynamic studies are gold standard to objectively diagnose lower urinary tract symptoms and dysfunction Aims and Objectives: To correlate clinical symptoms of lower urinary tract with urodynamic study to know whether urodynamics is really required routinely in patients with lower urinary tract symptoms (LUTS).

Methods: The study was conducted at Century hospital Hyderabad and Dr Lalitha's urogynaecology clinic Hyderabad, India during 15 days; from 2 September 2015 till 16 September 2015 with 48 patients. All cases coming to urogynaecology clinic who were taken up for urodynamic study were included. Statistical analysis was done by student's t test with $\mathrm{p}<0.05$ considered statistically significant.

Results: Total patients with urinary frequency were 13 out of which 7 (53.84\%) had cystometric capacity of less than $200 \mathrm{ml}$. Out of 16 patients with urgency and urge incontinence $10(62.50 \%)$ had high detrussor pressure during voiding. $50 \%$ patients had max cystometric capacity $<200 \mathrm{ml}$. Out of 7 patients with SUI (stress urinary incontinence) only one had genuine stress incontinence; all oth-ers had mixed incontinence with either raised EMG or raised Pdet. Out of 15 patients with com-plaints of voiding dysfunction $14(93.33 \%)$ had low flow rate that is Qmax $<15 \mathrm{ml} / \mathrm{sec}$. Out of 15 patients 2 had features of DSD (detrussor sphincter dyssynergia). Total 6 patients had raised EMG as cause for difficult voiding.

Conclusions: Detrusor sphincter dyssynergia as a cause of dysfunctional voiding is diagnosed using urodynamic study with EMG. Urodynamic study is important and useful tool to evaluate female lower urinary tract symptoms and unnecessary delay in doing a detailed urodynamics should be avoided.
\end{abstract}

Keywords: Detrussor sphincter dyssynergia, SUI. Urogynaecology, Urodynamic studies

\section{INTRODUCTION}

Urodynamic studies are gold standard to objectively diagnose lower urinary tract symptoms and dysfunction. ${ }^{1,2}$ Clinicians still hesitate to use it widely due to its invasive nature. But there is lot of difference between patient symptom complex and urodynamic findings which alter the course of management. This is the reason we have take-up the study in Indian city female population to know the significance of routinely doing urodynamic testing.

\section{Aims and objectives}

The present study was contemplated with the aim to correlate clinical symptoms of lower urinary tract with urodynamic study to know whether urodynamics is really 
required routinely in patients with lower urinary tract symptoms (LUTS).

\section{METHODS}

The study was conducted at Century hospital Hyderabad and Dr Lalitha's urogynaecology clinic Hyderabad, India during 15 days; from 2 September 2015 till 16 September 2015 with 48 patients.

\section{Inclusion criteria}

All cases coming to urogynaecology clinic who were taken up for urodynamic study were included.

Statistical analysis: Student's t test with $\mathrm{p}<0.05$ considered statistically significant.

\section{Study process}

History-a detailed history of clinical symptoms of LUTS taken in terms of storage symptoms (frequency, urgency, incontinence urge and stress) and voiding symptoms (hesistancy, thin stream, abdominal straining).

Urodynamic study- it was done by standardized method with normal values taken as follows: ${ }^{3}$
1. Post Void Residue (PVR) - $<50 \mathrm{ml}$

2. First desire to void: $150-200 \mathrm{ml}$

3. Cystometric capacity $>400 \mathrm{ml}$

4. No detrusor pressure rise on filling.

5. Low filling rate kept between $40-60 \mathrm{ml} / \mathrm{sec}$

6. Abdominal leak point pressure tested at $200-250 \mathrm{ml}$.

7. Cough leak recorded.

8. Normal detrusor pressure during voiding taken as Pdet $<40 \mathrm{cmH} 2 \mathrm{O}$.

9. Maximum flow rate (Qmax) for voided volume of more than $150 \mathrm{ml}$ to be $>15 \mathrm{ml} / \mathrm{sec}$.

\section{RESULTS}

Table 1: Correlation of urinary frequency with total cystometric capacity.

\begin{tabular}{|ll|}
\hline Cystometric capacity & Number of patients with \\
\hline$<200$ & 7 \\
\hline$>200$ & 6 \\
\hline Total & 13 \\
\hline
\end{tabular}

Table 2: Correlation of urgency/urge incontinence with maximum cystometric capacity and detrussor pressure during voiding and unstable detrusor activity.

\begin{tabular}{|llllllll|}
\hline $\begin{array}{l}\text { Cystometric } \\
\text { capacity }\end{array}$ & $\begin{array}{l}\text { Number of } \\
\text { patients }\end{array}$ & Pdet $<50$ & Pdet $>50$ & $\begin{array}{l}\text { Qmax } \\
>15 m / / s e c\end{array}$ & $\begin{array}{l}\text { Qmax } \\
<15 m / / s e c\end{array}$ & $\begin{array}{l}\text { EMG } \\
\text { normal }\end{array}$ & $\begin{array}{l}\text { EMG } \\
\text { raised }\end{array}$ \\
\hline$<200$ & 8 & 4 & 4 & 6 & 2 & 6 & 2 \\
\hline$>200$ & 8 & 4 & 4 & 6 & 2 & 7 & 1 \\
\hline Total & 16 & & & & & & \\
\hline
\end{tabular}

Table 3: Correlation of stress urinary incontinence with maximum cystometric capacity, demonstration of cough leak and voiding parameters.

\begin{tabular}{|l|llllllll|}
\hline $\begin{array}{l}\text { Number } \\
\text { of } \\
\text { patients }\end{array}$ & $\begin{array}{l}\text { Cysto } \\
\text { capacity }<200\end{array}$ & $\begin{array}{l}\text { Cysto } \\
\text { capacity }>\mathbf{2 0 0}\end{array}$ & $\begin{array}{l}\text { Pdet }<50 \\
\text { padet }>50\end{array}$ & $\begin{array}{l}\text { Qmax }>15 \\
\text { Qmax }<15\end{array}$ & $\begin{array}{l}\text { EMG } \\
\text { Normal }\end{array}$ & $\begin{array}{l}\text { EMGr } \\
\text { aised }\end{array}$ \\
\hline
\end{tabular}

Table 4: Correlation of voiding symptoms and urodynamic parameters.

\begin{tabular}{|lllllllll|}
\hline & Qmax $<15$ & Qmax $>15$ & Pdet<50 & Pdet $>$ 50 & EMG normal & EMG raised & PVR $<50$ & PVR $>50$ \\
\hline $\begin{array}{l}\text { Number } \\
\text { of } \\
\text { patients }\end{array}$ & 11 & 4 & 6 & 9 & 9 & 6 & 11 & 4 \\
\hline
\end{tabular}


Total numbers of patients with symptoms of urges and urge incontinence - 16 (Table 2).

Total patients with complaints of SUI were 7 (Table 3).

Total patients with complaints of thin stream, hesitancy and incomplete voiding were 15 (Table 4).

- Total patients with urinary frequency were 13 out of which $7(53.84 \%)$ had cystometric capacity of less than $200 \mathrm{ml}$.

- Out of 16 patients with urgency and urge incontinence $10(62.50 \%)$ had high detrussor pressure during voiding. $50 \%$ patients had $\max$ cystometric capacity $<200 \mathrm{ml}$.

- $\quad$ Out of 7 patients with SUI only one had genuine stress incontinence; all others had mixed incontinence with either raised EMG or raised Pdet.

- Out of 15 patients with complaints of voiding dysfunction $14(93.33 \%)$ had low flow rate that is Qmax $<15 \mathrm{ml} / \mathrm{sec}$

- Out of 15 patients 2 had features of DSD (detrussor sphincter dyssynergia).

- Total 6 patients had raised EMG as cause for difficult voiding.

\section{DISCUSSION}

The present study found that the relation between urinary frequency and cystometric capacity is not significant $(p>0.05)$. History of voiding dysfunction has significant correlation with low flow rates on uroflow. $93.33 \%$ patients having difficulty in micturition had low flow rates. But only urodynamic studies can appreciably tell the raised urethral sphincter tone as cause of obstruction.

The study by Linda Brubaker and colleague concluded that scores on urinary symptom scales were inadequate predictors of eventual urodynamic diagnosis. ${ }^{4}$

The study by Alessandro et al concluded that the diagnosis of overactive bladder based on urinary symptoms under diagnose the condition of detrusor instability in women with lower urinary tract symptoms. ${ }^{5}$

The study by Castleden et al concluded that there was no correlation between clinical and urodynamic findings. ${ }^{6}$

The study by B. Clark reported that urodynamic assessment provided useful information in women with lower urinary tract disorders, in developing principles of diagnosis and management. ${ }^{7}$

The study by Rizvi $M$ and Chughtai showed that there was poor correlation between clinical and urodynamic study and so the bladder is not a reliable source of identifying urinary symptoms in women. ${ }^{8}$
The stress incontinence symptom had insignificant correlation with urodynamics. Only $14 \%$ patients with symptoms of stress incontinence had genuine stress incontinence rest had mixed incontinence which would have been missed without urodynamic assessment.

The study by Weidner AC et al concluded that predictive value of stress symptoms alone was not high enough to serve as the basis for surgical management. ${ }^{9}$ Similar findings were reported by Nazli amir and colleagues. ${ }^{10}$

Our study as well as all the above mentioned studies concluded that urodynamic testing is mandatory in females with lower urinary tract symptoms and treatment based on symptoms alone is not adequate and accurate.

\section{CONCLUSION}

Frequency is not always due to low cystometric capacity and may be due to polyuria or detrusor instability and so urodynamic studies are needed. Patients with SUI have voiding dysfunctions which we need to know before surgery. Detrusor sphincter dyssynergia as a cause of dysfunctional voiding cannot be diagnosed unless urodynamic study with EMG is done. Urodynamics is important tool to evaluate female lower urinary tract symptoms and unnecessary delay in doing a detailed urodynamics should be avoided.

Funding: No funding sources

Conflict of interest: None declared

Ethical approval: The study was approved by the Institutional Ethics Committee

\section{REFERENCES}

1. Rosier PF. The evidence for urodynamic investigation of patients with symptoms of urinary incontinence; F1000 Prime Rep. 2013;5:8.

2. Amundsen C, Lau M, English SF, McGuire EJ. Urinary symptoms correlate with urinary findings? J Urol. 1999;161(6):1871-4.

3. Baharak A, Halifax NS, Farrell SA, Halifax NS, SOGC Committee Opinion on Urodynamics Testing. J Obstet Gynaecol Can. 2008;30(8):717-21.

4. Fitz Gerald MP, Brubaker L. Urinary incontinence symptom scores and urodynamic diagnoses. Neurourol Urodyn. 2002;21(1):30-5.

5. Digesu GA, Khullar V, Cardozo L, Salvatore S. Overactive bladder symptoms: do we need urodynamics? Neurourol Urodyn. 2003;22(2):105-8.

6. Castleden CM, Duffin HM, Asher MJ. Clinical and urodynamic studies in 100 elderly incontinent patients. $\mathrm{Br}$ Med J (Clin Res Ed). 1981;282(6270):1103-5.

7. Clarke B. The role of urodynamic assessment in the diagnosis of lower urinary tract disorders. International Urogynecology Journal. 1997;8(4):1969. 
8. Rizvi MR, Chughtai NG. Reliability of urodynamic interpretation in women presenting with urinary incontinence at a tertiary hospital. Urol Int. 2012;88(4):410-4.

9. Weidner AC, Myers ER, Visco AG, Cundiff GW, Bump RC. Which women with stress incontinence require urodynamic evaluation? Am J Obstet Gynecol. 2001;184(2):20-7.

10. Hameed N, Asghar MA, Waqar A. Urodynamic Findings in Female Patients Reporting With Lower
Urinary Tract Symptoms: J Ayub Med Coll Abbottabad. 2009;21(1).

Cite this article as: Joshi D, Lalitha K, Joshi $\mathrm{P}$, Saroshe S. A cross sectional study to assess the need of urodynamic studies in lower urinary tract patients attending an urogynaecology clinic. Int J Reprod Contracept Obstet Gynecol 2016;5:3675-8. 